The greatest inversion was recorded during the great frost of February, 1895, when at 9 a.m. on February 19 the summit was $17^{\circ} .6$ warmer than the base (Ben Nevis $33^{\circ} \cdot 6$, Fort William $16^{\circ} \cdot 0$ ). The longest continued inversion occurred during November 2-5, I897, when the summit temperature was the higher for fifty-eight consecutive hours, the mean daily temperature on November 4 being $9^{\circ} \cdot 7$ higher on Ben Nevis than at Fort William.

The Ben Nevis observations, of course, afford a comparison only between the conditions at the summit and those at the base of the mountain. It is more than probable that on many occasions when the summit temperature becomes nearly, though not quite, as high as that at the base, there is an inversion of temperature in part of the air-column between the summit and sea-level.

ANDREW WaTt

Scottish Meteorological Society, Edinburgh, April 12.

\section{Stanton Drew}

THE mysteries of this group of circles--the next in importance to those of Avebury and Stonehenge-are not yet fully unveiled, even by the very remarkable astronomical discoveries made in them by Sir Norman Lockyer or by his interesting description of them.

The diameter of the north-east circle is 97 English feet or 100 of an old Mediterranean foot of 11.64 inches. This is within an inch or two of the diameter of the outer sarsen ring at Stonehenge, which is in itself a very significant fact. The diameters of the south-western and central circles are respectively 150 and 380 of this old foot, so that the diameters of the circles (within a very slight working error) are in proportion one to the other of $5,7 \frac{1}{2}$, and 19 , the latter being the Metonic cycle number.

The distances between the various parts of the group, subject to a working error of from $\frac{1}{2}$ to $\frac{3}{1-1}$ of I per cent. only, are:-

Centre of cove through great circle to centre of northeast circle $=\mathrm{I} 4$ diameters of north-east circle.

Centre of great circle to Hauteville's Quoit $=5$ diameters of the great circle, or I9 diameters of the north-east circle, the latter being the Metonic cycle number.

Centre of south-west circle through great circle to Hauteville's Quoit $=7$ diameters of the great circle.

Centre of great circle to two stones too far to the west to be shown on the plan in Natcre $=9$ diameters of the great circle.

With the exception of the last, anyone can test these proportionate distances by the plan given in NATURE, but who will tell us what was the meaning or object of them?

\section{A. L. LEEWIS.}

\section{ALCOHOL IN INDUSTRY.}

THE committee, consisting of Sir Henry Primrose, K.C.B. (chairman), Sir W. Holland, M.P., Mr. I. Scott-Montagu, M.P., Sir William Crookes, Mr. Lothian Nicholson, Dr. Somerville, of the Board of Agriculture, Dr. Thorpe, the director of the Government Laboratories, and Mr. Thomas Tyrer, appointed last autumn by the Chancellor of the Exchequer to inquire into the use of duty-free alcohol in the arts and manufactures have got together their evidence and published their report with commendable promptitude. The report, we are glad to find, is unanimous, and this unanimity has doubtless not been without its influence in accelerating the business of the committee and the appearance of their report.

The subject, as was to be anticipated, has not been without its difficulties, for, as the committee state, a duty that yields more than twenty millions a vear is a public interest that cannot be triffed with: but, as usual when men are determined to find a solution, it is remarkable how purely academic difficulties tend to disappear. Now that the suggestions of the committee are before us, the wonder is that they should not have been given effect to a quarter of a century ago. We are afraid the delay does not reflect creditably upon the enterprise, energy, or constructive ability of the numerous groups of manufacturers who are interested in obtaining the greatest possible facilities in the use of duty-free alcohol in the arts. This attitude of laissez-faire is seen, and commented upon by the committee, in connection with the apathy and general ignorance of manufacturers with respect to the provisions of Section 8 of the Finance Act of I902, which gave the commissioners of Inland Revenue large discretionary powers as regards the use of spirit for industrial purposes. The committee point out that advantage has not been taken of the Act to the extent that might have been anticipated, and they have been surprised to find in examining the witnesses sent by the various Chambers of Commerce, who certainly ought to have had official knowledge of its existence, how very inadequate has been their acquaintance with its provisions.

In view of this general indifference one is tempted to inquire whether the manufacturers have had any real grievance, since they have made so little individual or collective effort to remove it. There is certainly no evidence that any collective effort has been made in the past, or, if it had been made, that the Treasury or the Revenue authorities would not have sympathised with it. The Exchequer, at all events since 1855 , when the present system of denaturing spirit came into existence, may be said to have disclaimed any idea of collecting a revenue on alcohol used solely as a raw material and for purely industrial purposes. If the hitherto existing system of denaturing and control had proved so irksome that the development of chemical industry was impossible, it might have been supposed that Parliament would have been troubled with the question long ago. But as an actual fact the languid interest of the chemical manufacturers needed, apparently, to be supplemented by the quickening influence of the internal-combustion engine, and the possible applications of spirit as a motor-fuel supplied to a jaded House of Commons engaged in the discussion of a Finance Bill that stimulus which was necessary to secure from the Chancellor the promise of the departmental inquiry, which it would seem the great body of manufacturing chemists was too lukewarm to ask for.

Great cry has been made in the past that the hindrances to a free and untrammelled supply of alcohol have cost us the coal-tar dye industry, which originated in this country, and at one time flourished here; but the committee apparently have had little difficulty in ascertaining how "little wool" there is in this cry. They say they are satisfied that the assertion, as a statement of historical fact, is destitute of substantial foundation. In their opinion the main cause which led to the decadence of the industry in this country is that which we have repeatedly insisted on in these columns, viz. the failure of those responsible for the management and for the finance of the industry here during the years $1860-1880$ to realise the vital importance of its scientific side, and their consequent omission to provide adequately for its development on that side.

It is true, however, that after signing the report, the two Members of Parliament named were induced to modify their assent to the unanimous finding of the committee as to the real cause of the decline of the coal-tar dye industry in this country. It will be interesting to see from the evidence, when this is published, what support Sir William Holland and Mr. John Scott-Montagu are able to find for the view thev express in their letter to the Chancellor.

In reality, "alcohol" plays a very small part in

No. $T 85 \mathrm{I}$, VOL. $7 \mathrm{I} 7$ 